\title{
The Relationship of Criminalistics and Criminal Law
}

\author{
Dr. Nyitrai Endre \\ Hungary
}

\begin{abstract}
Criminalistics Is Inseparable From Criminal Law And Criminal Procedural Law Since Its True Objective Is To Assist The Investigation Via Certain Principles And Recommendations. This Study Shall Introduce The Close Correlation And Integrity Of The Fundamental Principles Of Criminalistics Through The Elements Of General Statutory Provisions.
\end{abstract}

Keywords: Criminal Law, Fundamental Issues Of Criminalistics, Investigation, General Statutory Provisions (State Of Facts)

Should we aim to place criminalistics in the system of criminal sciences, it would be acknowledged as individual criminal science field within the scope of social sciences, somewhere in between law and political sciences and criminal sciences, alongside, for example, criminology and criminal sciences. Material criminal law defines criminal acts, while formally criminal procedural law regulates the order of criminal jurisdiction, stipulating the competent authorities and setting the rules of the state's law enforcement. ${ }^{1}$ Determining the statutory provisions of each criminal action criminal law not only stipulates the fundamental frames of criminalistics but also defines most types of criminalistics measures and objects. Moreover, as a compass, statutory provisions also designate the right path stipulating the facts criminalists need to determine to prove reasonable suspicion of crime. ${ }^{2}$

The subject of criminalistics can not be defined without the knowledge of material law, nevertheless, its methods can not be elaborated without the legal order of procedural regulations. Such objects are momentums of cognition that are based on experience, versions, plannability and analytical-evaluative approach, accompanied by freedom of choice. Criminalistics does not define its accomplishments as norms, but as recommendations that serve as guidelines to the understanding and reconstruction of the events of the past, or as directions for gathering and evaluating evidence, also to complete identification measures, without actually having the statutory nature of a legal norm. ${ }^{3}$

However, it might be controversial, whether the investigating authority may conduct evidentiary actions in its course of its procedure or it may only be completed throughout the court trial. GézaFinszteragrees that evidentiary procedures are conducted during the investigation. Specific elements of criminalistics might be present in the course of investigation as well, until the identification of the unknown perpetrator, whereas, from a cognitive approach, evidentiary procedures can be characterised by the actions conducted by a single authority based on presumable logical judgements, outlined in the suspicion of the criminal act, using the regression fallacy as in making predictions from the effect to the cause, gathering material and personal evidence. The investigating authority may - or in specific cases must - summarize the procedure and course of the investigation in a written report. The authority registers the information gathered in the course of its cognitive actions in the 'Robotzsaru' (Robocop) system. Furthermore, the investigative authority may determine to what extent this information can be proved, while the prosecutor's office may decide to what degree these provable facts are criminalised and constitute a criminal act. ${ }^{4}$ Detectives must investigate the state of facts that is to be further analysed upon the statutory provisions of law. ${ }^{5}$ Nevertheless, the investigation might get stuck and the authorities participating in the investigation remain clueless.

\footnotetext{
${ }^{1}$ CsongorHerke, Büntető eljárásjog (Criminal procedural law), 2007. Budapest-Pécs, p. 13

${ }^{2}$ GézaKatonA,A kriminalisztika és a bünügyi tudományok Gondolatok a 21. század kriminalisztikájáról)Criminalistics and criminal sciencesThoughts on the criminalistics of the 21st century), 2002, Budapest, p. 71

${ }^{3}$ FinSZTER,Géza, A büntetőeljárás segédtudományai I., Bizonyítás elméletek a jog világában. Szerk.: Tóth Éva - Belovics Ervin(Auxiliary sciences of criminal procedure I., Evidentiary theories in the word of law, Ed. Tóth, Éva - Belovics, Ervin), 2015, Budapest, pp. 98-103

${ }^{4}$ FINSZTER,see as cited above, pp. 104-107

${ }^{5}$ More and more scientific fields participate in the detection of the state of facts.We may refer to the example of criminal geography that offers new investigation methods in several aspects and cases of the investigative work. See more in: Mátyás,SzabolcsA bünözésföldrajz vitás kérdései. Földrajzi KözleményekA bünözésföldrajz vitás kérdései. Földrajzi Közlemények(Debated questions of criminal geography, In: Geographical Announcements), 2018, Budapest, pp. 102-109 
In such cases, possessing either or audio or visual evidence criminalistics linguist expert might be involved in the investigation who may analyse both the audio recordings and both the written evidence. ${ }^{6}$ Knowledge of criminal regulations provides a real opportunity to distinguish between important and, so the investigative authority may evaluate what elements of the state of facts have actual criminal relevance. ${ }^{7}$ Law enforcement authorities must be convinced about the true or false nature of the evidence, using their skills and competences in criminalistics, psychology and logics. ${ }^{8}$ The objective is the determination of the truth, however, while both the prosecutor and the investigating authority may achieve to get to the material truth in the period of the investigation, finally, only the court is entitled to determine such material truth that's coincident with reality in its judgement, in accordance with the statutory procedural provisions of Be. ${ }^{9}$ The cognitive process starts with observation, whereas the subject (investigating authority, prosecutor, judge) does not have a chance to come to know the past event directly, otherwise, becoming a witness, it would face the consequences of disqualification or conflict of interest, therefore, law enforcement authorities may only perceive the criminal act as a relevant event of the past indirectly, through the evidentiary procedure. ${ }^{10}$ The role of evidence gathered during the investigation and revealed to the prosecutor is to indicate the prosecutor to determine that the criminal act has been completed, it has been conducted by the perpetrator, furthermore, it can be proved by legitimate measures. ${ }^{11}$ Fundamental issues of criminalistics show close correlation with the elements of the general statutory provisions, namely with:

- the object,

- the material side,

- the subject,

- the personal side.

Statutory provisions may be divided to objective and subjective criteria. Objective criterions are those through which the act is reflected in the outside world, and actually becomes visible, furthermore, the tool of perpetration, etc. The objective criterions reflect the danger to society, they shape illicitness of the action, while subjective elements influence culpability. ${ }^{12}$

The object of the criminal act can be separated to two elements, first of all to the compulsory element of the legal subject, and second of all, to non-necessary element of the object of crime. Compulsory part of the material side of the general statutory provision is the criminal conduct that can either be active behaviour or failure (malpractice). The result and the criteria connected to the actual situation of the conduct are non-compulsory features of the material side. The object of the criminal act is the subjective compulsory element of the general statutory provision. Further necessary element of the personal side is culpability (deliberate or negligent conduct), while motive or intent are only noncompulsory features. ${ }^{13}$

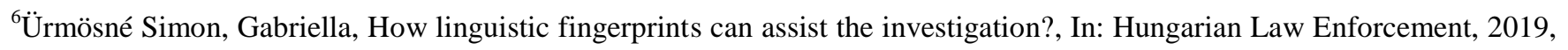
Budapest (under publication)

${ }^{7}$ GARAMVÖLGYI,Vilmos, Kriminalisztikai alapkérdések, Rendőrségi Szemle 1962. (X. évfolyam) 4. sz., (Fundamental questions of criminalistics, Police Journal, 1962, Issue 4. Vol. X.), Budapest, p. 321

${ }^{8}$ KATONA,Géza, Valós vagy valótlan? Értékelés a büntetőperbeli bizonyításban(Real or unreal? Evaluation in evidentiary procedure before court), 1990, Budapest, pp. 15-16

${ }^{9}$ BUDAHÁZI, Árpád, A műszeres vallomásellenőrzés, különös tekintettel a poligráfos vizsgálatra. A doktori értekezés tézisei, PTE ÁJK Doktori Iskola (Instrumental credibility examination, with special regards to polygraph examinations, Doctorate thesis, PTE Faculty of Law Doctorate course), 2013, Pécs, p. 8

${ }^{10}$ KATONA, see as cited above, p. 40. o.

${ }^{11}$ Bócz,Endre, Elgondolások a büntetőeljárás újrakodifikálásához,Belügyi Szemle, 1990/1. (Ideas to the recodification of criminal proceedings, Journal of Internal Affairs, 1990/1.), pp. 51-58

${ }^{12}$ Belovics, Ervin -BÉKÉs,Imre -Bush, Béla -MolnáR,Gábor -SinKu,Pál -Tóth,Mihály, Büntetőjog Általános Rész, Második, hatályosított kiadás, HVGORAC Lap- és Könyvkiadó Kft. (Criminal Law, General Provisions, Second, updated edition, HVGORAC Publishing), 2003., Budapest, p. 88

${ }^{13}$ BlAsKó, Béla, Magyar Büntetőjog Általános Rész. (Hungarian Criminal Law, General Provisions), 2002, Budapest, pp. $146-183$ 
We may categorise fundamental questions of criminalistics and the features of the statutory provisions as follows:

\begin{tabular}{|c|c|c|c|c|}
\hline \multicolumn{4}{|c|}{ System of general statutory provisions and the fundamental questions of criminalistics } \\
\cline { 2 - 5 } & \multicolumn{2}{|c|}{ Objective elements } & \multicolumn{2}{c|}{ Subjective elements } \\
\hline Compulsory elements & $\begin{array}{c}\text { Legal } \\
\text { subject }\end{array}$ & $\begin{array}{c}\text { Criminal conduct (active } \\
\text { behaviour, failure) }\end{array}$ & $\begin{array}{c}\text { Conditions of } \\
\text { becoming an object }\end{array}$ & $\begin{array}{c}\text { Culpability (deliberate, } \\
\text { negligent conduct) }\end{array}$ \\
\hline $\begin{array}{c}\text { Non-compulsory } \\
\text { elements }\end{array}$ & $\begin{array}{c}\text { Object of } \\
\text { crime }\end{array}$ & $\begin{array}{c}\text { Result, criteria related to } \\
\text { the situation of the } \\
\text { conduct }\end{array}$ & Special perpetrator & Intent, motive \\
\hline $\begin{array}{c}\text { Fundamental questions } \\
\text { of criminalistics }\end{array}$ & What? & Where? When? How? & Who? With whom? & Why? \\
\hline
\end{tabular}

Fundamental questions of criminalistics assist investigating authorities in determining the state of facts. However, more occasionally forensics linguistic experts might assist the procedure alongside the elementary issues of criminalistics, examining the so-called 'linguisticfingerprints'. The most important question to be answered by the authority is 'who did it or who wrote the text'? The objective of the forensics linguistic expert is to examine or identify the author. The issue might be approached from two perspectives: on the one hand, we may seek the answer whether the author of the seized text is the author of the text forced to be written by the suspect; on the other hand, the expert may determine the demographic-sociological features of the author of the incriminated text. ${ }^{14}$

In sum, we may state that the fundamental questions of criminalistics are connected to the general elements of the statutory provisions, so it is indispensable that criminalistics recommendations would respond to the challenges and cognition of the statutory provisions.

\section{Bibliography}

BELOVICS, Ervin - BÉKÉS,Imre - Bush, Béla - MolNÁR,Gábor - SINKU,Pál - TóTH,Mihály, Büntetőjog Általános Rész, Második, hatályosított kiadás, HVGORAC Lap- és Könyvkiadó(Criminal Law, General Provisions, Second, updated edition, HVGORAC Publishing), Budapest, p. 88

BLASKÓ, Béla, Magyar Büntetőjog Általános Rész. (Hungarian Criminal Law, General Provisions), 2002, Budapest, pp. 146-183

BóCZ,Endre, Elgondolások a büntetőeljárás újrakodifikálásához, Belügyi Szemle, 1990/1. (Ideas to the recodification of criminal proceedings), Journal of Internal Affairs, 1990/1., pp. 51-58

BUDAHÁZI,Árpád, A müszeres vallomásellenőrzés, különös tekintettel a poligráfos vizsgálatra. A doktori értekezés tézisei, PTE ÁJK Doktori Iskola (Instrumental credibility examination, with special regards to polygraph examinations, Doctorate thesis, PTE Faculty of Law Doctorate course), 2013, Pécs, p. 8

FinszTER,Géza, A büntetőeljárás segédtudományai I., Bizonyítás elméletek a jog világában. Szerk.: Tóth Éva Belovics Ervin, (Auxiliary sciences of criminal procedure I., Evidentiary theories in the word of law, Ed. Tóth, Éva - Belovics, Ervin), 2015, Budapest, pp. 98-103

GARAmVÖLGYI,Vilmos, Kriminalisztikai alapkérdések, Rendőrségi Szemle 1962. (X. évfolyam) 4. sz. (Fundamental questions of criminalistics, Police Journal, 1962, Issue 4. Vol. X.), Budapest, p. 321

CsongorHerke, Büntető eljárásjog. (Criminal procedural law), 2007, Budapest-Pécs, p. 13

KATONA,Géza, Valós vagy valótlan? Értékelés a büntetőperbeli bizonyításban(Real or unreal? Evaluation in evidentiary procedure before court), 1990, Budapest, pp. 15-16

KATONA, Géza, A kriminalisztika és a bünügyi tudományok Gondolatok a 21. század kriminalisztikájáról (Criminalistics and criminal sciences Thoughts on the criminalistics of the 21st century), 2002, Budapest, p. 71

Mátyás, Szabolcs, A bűnözésföldrajz vitás kérdései. Földrajzi Közlemények(Debated questions of criminal geography, In: Geographical Announcements), 2018,Budapest, pp. 102-109

Ürmös Simon,Gabriella, Miben segítik a nyelvi ujjlenyomatok a nyomozást? Magyar Rendészet, Budapest, 2019. (megjelenés alatt)(How linguistic fingerprints can assist the investigation?, In: Hungarian Law Enforcement, 2019, Budapest) (under publication)

\footnotetext{
${ }^{14}$ Ürmösné Simon, Gabriella, Miben segítik a nyelvi ujjlenyomatok a nyomozást? Magyar Rendészet, Budapest, 2019. (megjelenés alatt) (How linguistic fingerprints can assist the investigation? In: Hungarian Law Enforcement, 2019, Budapest) (under publication)
} 